\title{
Effect of the inclusion of herbal phosphatidylcholine on palatability, digestibility and metabolisable energy of the diet in dogs
}

\author{
Germán D. Mendoza Martíneza , Miguel Á. López ${ }^{b}$, Pedro A. Hernández Garcíac, \\ Josué J. Ríos Hilario ${ }^{\mathrm{d}}$, Javier González ${ }^{\mathrm{e}}$, Adrian Gloria Trujillo ${ }^{\mathrm{a}^{*}}$
}

\begin{abstract}
This study aimed to evaluate the palatability, nutrient digestibility, metabolisable energy (ME) and faecal characteristics of diets in dogs fed increasing levels of herbal phosphatidylcholine (herbal mix) versus an unsupplemented diet (with only $377 \mathrm{mg}$ choline provided by $1 \mathrm{~kg}$ food) or choline chloride ${ }^{1}$ (2000 $\mathrm{mg}$ choline $/ \mathrm{kg}$ food) in 40 adult dogs. In experiment 1 , a palatability test was conducted to make two pairwise comparisons: 0 versus 200; and 0 versus $400 \mathrm{mg} / \mathrm{kg}$ herbal mix. In experiment 2, a digestibility test was performed to evaluate herbal mix at $0,200,400$ and $800 \mathrm{mg} / \mathrm{kg}$ and $2000 \mathrm{mg}$ choline provided by choline chloride. Results from experiment 1 indicated that the dogs preferred diets containing herbal mix to the unsupplemented diet $(P<0.05)$. In experiment 2 , nutrient digestibility and faecal characteristics were not influenced by the treatment $(P<0.059)$. The inclusion of $400 \mathrm{mg} / \mathrm{kg}$ of herbal mix increased the ME (quadratic effect, $P<0.01$ ). In conclusion, the results of this study indicate that the inclusion of a herbal mix rich in phosphatidylcholine (1.6\%) and other methylated metabolites at $400 \mathrm{mg} / \mathrm{kg}$ can fully replace choline chloride in dog diets.

Key words: Canis familiaris, feed plant additive, pet food, taste preferences.
\end{abstract}

\section{INTRODUCTION}

Choline is a "quasi-vitamin" (Morrison et al 2018) and one of its metabolic pathways is the formation of phosphatidylcholine, the main component of the cell membrane and lipoproteins (Vance and Vance 2008). The NRC (2006) recommendations for choline are based on the results of experiments conducted in the 1930s and 1940s (AAFCO 2015). An evaluation of 75 diets for healthy adult dogs (homemade diets) showed that more than 50\% did not meet the choline requirements (Pedrinelli et al 2019). However, the needs could be overestimated (German et al 2015) and, consequently, both the requirement and different forms of the nutrient must be reviewed in a broader sense. Feeds supply choline in different forms: free choline (Cho), glycerophosphocholine (GPC), phosphocholine (Pcho), phosphatidylcholine (Ptdcho) and sphingomyelin $(\mathrm{SM})^{2}$ all of which may differ in bioavailability (Cheng et al

Received: 22.12 .2020 .

Accepted: 20.04.2021.

aDoctorado de Ciencias Agropecuarias. Universidad Autónoma Metropolitana - Xochimilco, México.

${ }^{\mathrm{b}}$ Consultor Nutricionista de Mascotas, Atizapán, Estado de México, México. ${ }^{\mathrm{c}}$ Centro Universitario Amecameca, Universidad Autónoma del Estado de México, México.

${ }^{\mathrm{d} F a c u l t a d}$ de Estudios Superiores Cuautitlán, Universidad Nacional Autónoma de México, México.

${ }^{\text {e} N u p r o x a ~ S w i t z e r l a n d, ~ E t o y, ~ S w i t z e r l a n d . ~}$

*Corresponding author e-mail: agloria@correo.xoc.uam.mx

1 Surfamex S.A. de C.V.

2 USDA, United States Department of Agriculture. 2008. Database for the choline content of common foods; release 2. Nutrient Data Laboratory, Beltsville Human Nutrition Research Center, USDA. Availble at: https://data.nal.usda.gov/dataset/usda-database-cholinecontent-common-foods-release-2-2008
1996, Lewis et al 2016), transport mechanisms (Sheard and Zeisel 1986), lost by microbial metabolism (Zeisel et al 1989) and ATP expenditures to be available in the cells (Fagone and Jackowski 2013).

Phosphatidylcholine is a central metabolite in the functions associated with choline (Zeisel and da Costa 2009). There is evidence that a herbal mix containing Achyranthes aspera, Azadirachta indica, Citrullus colocynthis, Trachyspermum ammi and Andrographis paniculata contributes with phosphatidylcholine $(16 \mathrm{~g} / \mathrm{kg}$ herbal mix) and other methylated metabolites (Roque et al 2020). Several species of domestic animals replace choline chloride by the herbal mix. In broilers, bird performance was similar with herbal choline and synthetic choline (Calderano et al 2015). In finishing lambs, Godínez-Cruz et al (2015) reported the same performance with $4 \mathrm{~g} / \mathrm{d}$ of herbal mix versus $4 \mathrm{~g} / \mathrm{d}$ of a rumen-protected choline (25\% choline), whereas Crosby et al (2017) used the same source choline levels and reported a large bodyweight gain during gestation in suckling ewes. In dairy cows, the herbal mix $(17 \mathrm{~g} / \mathrm{d})$ increased milk production, and improved fertility and health (Gutiérrez et al 2019).

Synthetic choline (choline chloride) has high hygroscopicity (Calderano et al 2015) and is a highly reactive compound that requires attention during the preparation of premixes. Herbal choline, on the other hand, is stable but has aromatic volatile compounds (Mendoza et al 2019) that could affect the palatability of canines (Wynn and Fougere 2007). Herbal mix has the advantage of providing nutraceutical metabolites (Roque et al 2020) that can be beneficial for health (Di Cerbo et al 2017). Therefore, the objective of this experiment was to evaluate the effects of increasing the dietary levels of a herbal mix rich in phosphatidylcholine and other methylated metabolites on food palatability, nutrient digestibility, metabolisable energy content, as well as on faecal characteristics, compared to a 
not supplemented diet or a diet with supplemented choline chloride in dogs.

\section{MATERIAL AND METHODS}

The experiments were approved by the Academic Committee for Animal Use of the Doctoral Program in Animal Science and Agriculture of the Universidad Autónoma Metropolitana and were conducted in the Centro de Investigación en Alimentos para Mascotas (CIAM), in Tepeji del Rio, Hidalgo, México.

The basal diet (table 1) was extruded to kibbles (Dosky PT290, Canis Food Nutrition) and it was formulated following the nutritional recommendations of NRC (2006) and the Association of American Feed Control Officials (AAFCO 2015) for adult dogs. The vitamin and mineral premixes were manufactured by DSM Nutritional Products of Mexico. Herbal mix (BioCholine ${ }^{\circledR}$, Nuproxa México -Switzerland) and choline chloride (52\% choline, Surfamex SA de CV) were used to prepare the following dietary treatments: unsupplemented diet (with only 377 mg choline/kg food), choline chloride (2000 mg choline/ $\mathrm{kg}$ of diet) and three levels of herbal mix (200, 400 and $800 \mathrm{mg} / \mathrm{kg}$ ) with a phosphatidylcholine concentration of $1.6 \%$.

The inclusion content of choline (provided by choline chloride) in the diet was established according to the choline requirements for an adult dog (NRC 2006). The amount of $400 \mathrm{mg} / \mathrm{kg}$ of herbal mix was based on a previous experiment where it was concluded that a unit of herbal mix can replace five units of choline chloride (Mallo and Paolella 2017). Productive performance in calves (Díaz-Galvan et al 2021) has shown a quadratic response, therefore herbal mix concentrations included a low $(200 \mathrm{mg} / \mathrm{kg})$ and upper $(800 \mathrm{mg} / \mathrm{kg})$ concentration.

Diets were stored for 15 days in sealed bags protected from direct sunlight at a room temperature of $20.5 \pm$ $1.2{ }^{\circ} \mathrm{C}$ and relative humidity of $68.5 \pm 2.3 \%$ before being supplied to the dogs. The ingredient composition of the basal diet and the analysed chemical composition of the experimental diets are shown in table 1.

Forty (twenty males and twenty females) healthy adult dogs (Canis lupus familiaris: $4.6 \pm 1.6$ years old, dewormed and vaccinated) were individually housed in concrete kennels ( $2 \mathrm{~m}$ width $\mathrm{x} 5 \mathrm{~m}$ long). The dogs were Beagles (23), Schnauzer (8), Bichón Friseé (3), Dachshund (3), Airedale Terrier (2) and Jack Russell (1).

\section{EXPERIMENT 1 - PALATABILITY STUDY}

Two palatability tests were performed in two pairwise comparisons: 0 versus $200 \mathrm{mg} / \mathrm{kg}$ and 0 versus $400 \mathrm{mg} / \mathrm{kg}$ herbal mix using a pair-wise diet comparison with trained dogs as described by Felix et al (2012) in 30 min periods
Table 1. Ingredient composition of basal diet (g/kg, as fed).

\begin{tabular}{lc}
\hline Ingredient & $\mathrm{g} / \mathrm{kg}$ \\
\hline Maize & 467.0 \\
Meat meal & 250.0 \\
Corn gluten meal & 60.0 \\
Regular soybean meal (460 g crude protein/kg) & 50.0 \\
Poultry fat & 50.0 \\
Wheat meal & 44.0 \\
Wheat bran & 40.0 \\
Swine liver hydrolysate & 20.0 \\
Experimental premix (vitamins, minerals and NaCl) & 11.44 \\
Sand & 3.0 \\
Yeast cell wall and beta glucan & 1.5 \\
Calcium propionate & 1.0 \\
Sodium butirate & 1.0 \\
Caramel coffee & 0.4 \\
Titanium dioxide & 0.66 \\
Total & 1000 \\
\hline Chemical composition & $\%$ \\
Dry matter intake & 90.50 \\
Crude protein & 24.05 \\
Crude fiber & 2.56 \\
Ether extract & 12.05 \\
Ash & 12.71 \\
\hline
\end{tabular}

for two consecutive days calculating the food preference according to the intake ration of $\operatorname{diet} \mathrm{A}$ as:

$$
\text { Intake ratio }=\left[\frac{g \text { of diet } A \text { or } B \text { intake }}{g \text { of total food offered }(A+B)}\right] \times 100
$$

The dogs used in food preference were evaluated to discard left and right-sided laterality according to record tests and quality tests where dogs were fed the same food and significant differences were not expected (Tobie et al 2015).

Statistical analysis. Data were analysed with R software (v 2.15.3, Auckland, New Zealand) package fdANOVA (Górecki and Smaga 2019). The results of palatability were analysed considering 40 observations per test (20 dogs $\times$ two days per test). The data obtained on the relationship or proportion of consumption were first analysed with the Kruskal-Wallis test, which did not reveal any influence $(P>0.05)$ of breed, gender (male and female), or test day on consumption preference. The normality of the data was tested and then a Kruskal Wallis test and a t-test were performed to determine whether the consumption preference data of the herbal mix diets were different from 0.50 with a significance level of $1 \%$. 
EXPERIMENT 2 - DIGESTIBILITY ASSAY

Dogs were randomly allocated into 5 dietary treatments which consisted of the unsupplemented diet (negative control), the diets supplemented with the herbal mix at different concentrations (200, 400 and $800 \mathrm{mg} / \mathrm{kg}$ ) and the diet supplemented with choline chloride (positive control, $2000 \mathrm{mg}$ choline/ $\mathrm{kg}$ food), with eight repetitions per treatment. The assay lasted 17 days, leaving the last 5 days of this period for total faeces collection (AAFCO 2015). Dogs were weighed to allocate enough food to meet their metabolisable (ME) energy requirements

$\left[\right.$ ME, Mcal / d $=130 \times\left(\right.$ Body weight, $\left.\left.\mathrm{kg}^{0.75}\right)\right](\mathrm{NRC} 2006)$ by providing food once a day (10:00 $\mathrm{h})$. Water was freely available and feed consumption was recorded daily.

Digestibility was performed using the total faecal collection method for five days (Corsato and Gregory, 2018) after 12 days of adaptation to the experimental diets. Total faeces from dogs were collected twice daily with spatula and forceps, faeces were stored in plastic bags and stored at $-20{ }^{\circ} \mathrm{C}$ until analysis (Corsato and Gregory 2018). Feed (kibbles) and faeces were oven dried and analysed for dry matter (AOAC method 934.01), crude protein (AOAC method 2001.11), ether extract (AOAC method: 954.02 for feed with acid hydrolysis, and 920.39 for faeces with diethyl ether), and ash (AOAC method 942.05) (AOAC 2015). Neutral detergent fibre (NDF) was analysed with thermostable amylase and acid detergent fibre (ADF) according to Van Soest et al (1991). Gross energy was determined with an adiabatic bomb calorimeter (Parr Instrument Company, Moline, IL). The apparent digestibility of crude protein, ether extract, ash, and ADF was estimated. The ME was calculated using the equations of the NRC (2006), estimating energy losses in the urine based on the protein content of the food (Duque-Saldarriaga et al 2017).

The faecal score was also evaluated for five consecutive days using conventional scores from 1 to 5 , considering a score 1 as hard and dry faeces, 2 as hard, formed and dry faeces, 3 as soft, formed and moist faeces (it retains shape), 4 as soft and unformed faeces (faeces take the shape of container) and 5 as watery (liquid) faeces without shape (Clapper et al 2001).

Statistical analysis. Data were analysed with R software (v 2.15.3, Auckland, New Zealand) package fdANOVA (Górecki and Smaga 2019). The normality was analysed using Shapiro-Wilk test and then data were analysed according to a complete randomised design, with 5 treatments and a total of eight replicates per treatment. The means of dry matter intake, nutrients digestibility and metabolisable energy with herbal mix $(200,400$ y $800 \mathrm{mg} / \mathrm{kg}$ ) and choline chloride (2000 mg choline/kg basal diet) were compared with orthogonal contrasts. Linear and quadratic effect of treatments inclusion levels on response variables were evaluated with orthogonal polynomial contrasts. Faecal scores were analysed with a Kruskal-Wallis test $(P<0.05)$. The faecal score was reported as means as according to Carciofi et al (2009).

\section{RESULTS}

\section{EXPERIMENT 1 - PALATABILITY STUDY}

Dogs consumed a greater quantity of food when the diets contained herbal mix which resulted in a higher intake ratio $(P<0.001)$ in the two pairwise comparisons (table 2). The consumption index was higher than 0.5 and the t-test confirms that the dogs had a preference for foods with herbal mix $(P<0.001)$ in the two trials.

\section{EXPERIMENT 2 - DIGESTIBILITY ASSAY}

The results of the digestibility test and the metabolisable energy values are shown in table 3. Intake was similar among treatments $(P>0.05)$ and nutrient digestibility was

Table 2. Preference test of $\operatorname{dogs}^{\gamma}$ fed paired diets with different concentrations of herbal mix.

\begin{tabular}{lccc}
\hline & Intake index & CI \\
\cline { 2 - 4 } & & Lower & Upper \\
\hline Assay 1 & & & \\
Control & $0.3384^{\mathrm{b}}$ & 0.281 & 0.395 \\
Herbal mix**, $200 \mathrm{mg} / \mathrm{kg}$ & $0.6615^{\mathrm{a} *}$ & 0.604 & 0.718 \\
Assay 2 & & & \\
Control & $0.3697^{\mathrm{b}}$ & 0.295 & 0.444 \\
Herbal mix, $400 \mathrm{mg} / \mathrm{kg}$ & $0.6303^{\mathrm{a} *}$ & 0.556 & 0.705 \\
\hline
\end{tabular}

CI: Confidence interval

$\gamma$ : Forty dogs per test.

* The value means that the intake ratio of the diets with herbal mix was different from 0.50 according to the $\mathrm{T}$ test $(P<0.001)$, ${ }^{\text {ab }}$ Values with different literals within the column are different $(P<0.0001)$.

** The phosphatidylcholine concentration in herbal mix is $1.6 \%$. 
Table 3. Effect of herbal mix level versus choline chloride on nutrient digestibility and metabolisable energy in dog diets.

\begin{tabular}{|c|c|c|c|c|c|c|c|c|c|}
\hline \multirow[b]{2}{*}{ Item } & \multirow[b]{2}{*}{0} & \multicolumn{2}{|c|}{ Herbal mix*, mg/kg } & \multicolumn{3}{|c|}{$\begin{array}{c}\text { Choline chloride, } \\
\mathrm{mg} / \mathrm{kg}\end{array}$} & \multicolumn{3}{|c|}{$P$-value } \\
\hline & & 200 & 400 & 800 & $2000 * *$ & SEM & $\mathrm{L}$ & Q & Contrast*** \\
\hline Dry matter intake, $\mathrm{g} / \mathrm{d}$ & 231.1 & 236.3 & 239.0 & 227.2 & 239.9 & 22.5 & 0.97 & 0.66 & 0.90 \\
\hline \multicolumn{10}{|l|}{ Nutrients digestibility, $\%$} \\
\hline Dry matter & 76.7 & 77.5 & 79.0 & 77.4 & 77.6 & 1.71 & 0.67 & 0.49 & 0.87 \\
\hline Crude protein & 86.8 & 86.6 & 85.1 & 84.7 & 86.4 & 1.65 & 0.29 & 0.93 & 0.62 \\
\hline Ether extract & 83.3 & 76.2 & 87.8 & 80.9 & 83.8 & 2.98 & 0.72 & 0.97 & 0.64 \\
\hline Acid detergent fibre & 32.6 & 37.0 & 32.2 & 38.3 & 35.3 & 5.56 & 0.61 & 0.87 & 0.92 \\
\hline Gross energy & 88.3 & 88.7 & 86.7 & 87.3 & 88.6 & 1.25 & 0.40 & 0.95 & 0.41 \\
\hline \multicolumn{10}{|l|}{ Metabolisable energy } \\
\hline Mcal/kg & 3.67 & 3.73 & 3.86 & 3.70 & 3.8 & 0.04 & 0.23 & 0.01 & 0.99 \\
\hline
\end{tabular}

* The phosphatidylcholine concentration in herbal mix is $1.6 \%$.

** This is equivalent to $2000 \mathrm{mg}$ choline $/ \mathrm{kg}$ food. The choline is supplied with a choline chloride product with $60 \%$ of choline.

*** Contrast: Herbal mix vs. choline chloride

SEM: Standard error of the mean, L: Linear effect, Q: Quadratic effect.

Table 4. Consistency of faeces by treatment and statistical information.

\begin{tabular}{lccccc}
\hline & \multicolumn{3}{c}{ Herbal mix*, $\mathrm{mg} / \mathrm{kg}$} & Choline chloride, $\mathrm{mg} / \mathrm{kg}$ \\
\cline { 2 - 6 } & 0 & 200 & 400 & 800 & $2000^{* *}$ \\
\hline Faecal score & 2.70 & 2.95 & 2.90 & 2.80 & 2.62 \\
Coefficient of variation, $\%$ & & & 12.9 & & \\
Kruskal-Wallis test & & & & \\
Chi-square test & & 4.46 & \\
$P$ value & & 0.34 & \\
Shapiro-Wilk test & & 0.57 & \\
\hline
\end{tabular}

* The phosphatidylcholine concentration in herbal mix is $1.6 \%$.

** This is equivalent to $2000 \mathrm{mg}$ choline/kg food. The choline is supplied with a choline chloride product with $60 \%$ of choline.

Index scale: 1 = very hard and dry stools; score; 5 = pasty stools.

not affected by the treatments. The inclusion of the herbal mix showed an increase $(P<0.01$, quadratic response) in the metabolisable energy of the ration with the highest values with the intermediate concentrations of the herbal mix $(400 \mathrm{mg} / \mathrm{kg}$ ). Faecal characteristics of the dogs fed diets with increasing levels of herbal mix or choline chloride were not different $(P>0.05$, table 4$)$.

\section{DISCUSSION}

\section{EXPERIMENT 1 - PALATABILITY STUDY}

A previous study comparing the dietary supplementation of $500 \mathrm{mg} / \mathrm{kg}$ of herbal mix against $2000 \mathrm{mg}$ of choline chloride showed the feasibility of replacing the synthetic product without affecting dog acceptability (Mallo and
Paolella 2017). The herbal mix is composed, among other plants, by Azadirachta indica, a medicinal plant recognised for its bitter taste (Ogbuewu et al 2011). This characteristic, together with the carnivorous nature of the dogs and their olfactory capacity, made us expect a lower intake of the food supplemented with herbal mix. In contrast, there was a higher preference defined as a relatively high probability of ingesting one of two available foods under specific conditions (Griffin and Bleider 1984), presumably associated with the secondary metabolites of other plants in the mixture. The herbal mix includes Trachyspermum ammi which contains thymol (Vitali et al 2016) which is an essential oil that has significantly stimulated consumption in pigs (Michiels et al 2012). The herbal mix contains more than 100 volatile compounds among which is $(\mathrm{Z})$ -2-octenal (Mendoza et al 2018, Mendoza et al 2019), 
a volatile compound present in many plants, fruits and flowers (Chen et al 2016, Tietel and Masaphy 2017) that has shown to stimulate the olfactory epithelium in rats (Araneda et al 2004).

Food preference can be associated with intrinsic feed factors but also with external conditions in dogs; Koppel et al (2013) pointed out that the presence of ingredients with secondary metabolites such as alcohols, aldehydes, ketones, esters, sulfur compounds, pyrazines, furans, alkanes, derived from benzene and terpenes resulted in complex odour characteristics that can be associated with the acceptability of the food by the dog and the results showed that the probability of dogs rejecting food with herbal mix is very low, but information on the intake for longer periods is required since there are some limitations presented by the short tests or others related to preference procedures as described by Griffin and Bleider (1984).

\section{EXPERIMENT 2 - DIGESTIBILITY ASSAY}

The digestibility of dry matter in commercial dog foods has been reported in the range of 89 to $94 \%$ (Alvarado et al 2008). However, similar values to those observed in this study have been reported particularly for maize or sorghum based diets (de Oliveira et al 2012). Nevertheless, the effects of choline, choline-contributing compounds or herbal sources on DM digestibility have not been reported.

In this experiment, the possibility of some effect of the herbal mix on digestibility was considered, since it provides phosphatidylcholine (also known as lecithin) (Demattê Filho et al 2015). Phosphatidylcholine is a metabolite that participates in the solubilisation of bile acids (Barrios and Lichtenberger 2000) and it is recognised that choline phospholipids are important for lipid digestion in the small intestine by the combined action of pancreatic phospholipase A2 IB and mucosal enzymes (jejunoileal brush border phospholipase B/lipase and mucosal secreted phospholipase A2 X) (Nilsson and Rui -Dong Duan 2019). The phospholipase $A 2$ is the predominant digestive enzyme in the pancreatic juice and with the colipase, cleaves the ester linkages in the triacylglycerol releasing two free fatty acids and monoacylglycerol (Murota 2020). The lack of response in digestibility suggests that the contribution of choline-related compounds (free choline, Cho), glycerophosphocholine (GPC), phosphocholine (Pcho), phosphatidylcholine (Ptdcho) and sphingomyelin (SM) in the basal diet have been sufficient to contribute to the dietary phospholipids for the various functions in the digestion and absorption of essential fatty acids (Murota 2020). Based on tables provided by the USDA (2008) we estimated a concentration of total choline of $377 \mathrm{mg} / \mathrm{kg}$ (calculated as the sum of Cho, GPC, Pcho, Ptdcho, and SM) in the unsupplemented diet which would have resulted in an intake lower than the dog nutrient requirement (NRC 2006). However, the nutritional requirement for choline in dogs requires a review as other studies have observed that intakes below $40 \mathrm{mg} / \mathrm{d}$ of choline give similar results (German et al 2015). The results of fat digestibility were lower than those reported in other studies with dogs, with values above $90.1 \%$ (Donadelli and Aldrich 2019, Jackson et al 2020) and even values of 94\% (de Souza et al 2019).

The absence of changes in the digestibility coefficients coincides with the faecal score since these two variables are related (Brambillasca et al 2010). This indicated that there were no differences in faecal matter excreted, consistency (Sunvold et al 1995), or fermentation in the colon (Donadelli and Aldrich 2019) presumably with no changes in water flow to the lumen (Felix et al 2013), which determines moisture in the stool (Donadelli and Aldrich 2019). The average faecal scores observed in this study (close to 3 ) is desirable for pet owners (Clapper et al 2001).

The use of herbal mix ( $400 \mathrm{mg} / \mathrm{kg}$ food) increased the ME by $5.03 \%$, compared to the negative control. Similar results were observed in lambs, where the use of the same herbal additive translated in a higher daily gain due to an increment of the available energy in the feed (MartínezAispuro et al 2019). The higher ME content in the dog food with intermediate doses of herbal mix could be explained by three mechanisms that may be occurring at the same time. First, phosphatidylcholine from herbal mix follows a different metabolic pathway than free choline from choline chloride, expending less metabolic energy to be available for cells. In addition, free choline requires transporters that use ATP and also requires an ATP molecule in the formation of phosphocholine (Fagone and Jackowski 2013), while phosphatidylcholine is absorbed with other products of fat digestion, it is transported in the blood as lipoproteins and is directly available to cells and tissues directly (Tocher et al 2008). The second hypothesis that explains the higher content of ME could be related to the presence of methyl groups and hexadecanoic acid (C16: 0 ) in the herbal mix (Roque et al 2020) that act as methyl group donors (Hui-Chao et al 2016). The latter could have improved fat utilisation at the cellular level (Pissios et al 2013) or could have saved methionine as observed in other species (Dilger et al 2007, Sales et al 2010). A study in dogs with low methionine levels showed how the oxidation of choline was increased, presumably for methionine synthesis (Harrison et al 2020). The third possible mechanism involves the regulation of the gene expression of key allosteric effector enzymes of lipid and glucose metabolism as demonstrated by White et al (2019) in broiler chickens fed herbal mix. These authors observed a $39.03 \%$ and $14.61 \%$ increase in the gene expression of PPAR receptors and adiponectin, respectively, in liver tissue when compared with choline chloride. They concluded that the herbal mix increased the efficiency of nutrients utilisation.

The quadratic response on ME can be explained by different metabolites contained in the herbal mix which, in other animal species, have shown that growth is improved until an optimum dietary herbal additive inclusion level 
and then performance decreases with increasing the levels of inclusion (Gabriel 2019, Razo et al 2020). Achyrantes aspera is a source of oleanolic acid linked to oligosaccharides (Goyal et al 2007), Azadirachta indica contains acarbose (Mukherjee and Sengupta 2013) and Citrullus colocynthis contains lectin, heterogeneous proteins linked to specific oligosaccharides (Ramzi et al 2013). All of them are present in the herbal mix which, at a certain threshold level, could negatively affect and reduce the values of ME (Chen et al 2013).

Choline chloride is commonly used to provide choline in balanced dog foods, but it is known to affect the activity of other elements of the premix due to its hygroscopic properties (Moghimi and Roosta 2019). Substitution of choline for phospatydilcholine in dogs (originating from a crustacean) indicated that it is feasible to use this source to maintain physiological levels of choline and its metabolites in plasma (Burri et al 2019). Studies in lactating rats fed with phospatydilcholine have confirmed the previous statement through phospatydilcholine measurements in the plasma of suckling pups and immune response, due to its contribution to splenocytes (Lewis et al 2016). Our findings should be complemented with long-term evaluations to assess whether choline chloride can be replaced with a herbal source without affecting long-term health, particularly liver and cardiovascular health, and to confirm the protective effects of this nutrient related to glucose and lipid metabolism. In conclusion, the results of this study showed that the herbal mix rich in phosphatidylcholine (1.6\%) and other methylated metabolites can fully replace choline chloride in dog diets.

\section{ACKNOWLEDGEMENTS}

The authors would like to thank Nuproxa México and Nuproxa Switzerland for donating the herbal additive BioCholine.

\section{REFERENCES}

AAFCO, Association of American Food Control Officials. 2015. Official Publication. Sacramento, California, USA.

Alvarado CA, Hodgkinson SM, Alomar D, Boroschek D. 2008. Evaluation of the chemical composition of dry dog foods commercialized in Chile used for growing dogs. Arq Bras Med Vet Zootec 60, 218-226.

AOAC, Association of Analytical Chemists International. 2005. Official Methods of Analysis of the Association of Analytical Chemists International. $18^{\text {th }}$ ed. Association of Official Analytical Chemists, Gathersburg, Maryland, USA.

Araneda RC, Peterlin Z, Zhang X, Chesler A, Firestein S. 2004. A pharmacological profile of the aldehyde receptor repertoire in rat olfactory epithelium. $J$ Physiol 555, 743-756.

Barrios JM, Lichtenberger LM. 2000. Role of biliary phosphatidylcholine in bile acid protection and NSAID injury of the ileal mucosa in rats. Gastroenterology 118, 1179-1186.

Brambillasca S, Purtscher F, Britos A, Repetto LJ, Cajarville C. 2010. Digestibility, fecal characteristics, and plasma glucose and urea in dogs fed a commercial dog food once or three times daily. Can Vet J 51, 190-194.

Burri L, Heggen K, Berg SA. 2019. Phosphatidylcholine from krill increases plasma choline and its metabolites in dogs. Vet World 12, 671-676.
Calderano AA, Nunes RV, Rodrigueiro RJB, César RA. 2015. Replacement of choline chloride by a vegetal source of choline in diets for broilers. Ciênc Anim Bras 16, 37-44.

Chen JM, Song JY, He J, Gu XR, Zhang X. 2016. Studies on volatile components in the flowers of Cymbidium goeringii and Cymbidium faberi from Qinling mountains. Acta Hort Sin 43, 2461-2472.

Chen X, Parsons MC, Bajjalieh N. 2013. Nutritional evaluation of new reduced oligosaccharide soybean meal in poultry. Poult Sci 92, 1830-1836.

Cheng WL, Holmes-McNary MQ, Mar MH, Lien EL, Zeisel SH. 1996. Bioavailability of choline and choline esters from milk in rat pups. J Nutr Biochem 7, 457-464.

Clapper MG, Grieshop MC, Merchen RN, Russett CJ, Brent LJ, et al. 2001. Ileal and total tract nutrient digestibilities and fecal characteristics of dogs as affected by soybean protein inclusion in dry, extruded diets. J Anim Sci 79, 1523-1532.

Corsato AI, Gregory AC. 2018. The effect of sorghum fractions on apparent total tract digestibility and antioxidant capacity by dogs. Plos One 13, e0206090.

Crosby M, Mendoza-Martínez GD, Relling A, Vázquez VA, Lee-Rangel HA, et al. 2017. Influence of supplemental choline on milk yield, fatty acid profile, and postpartum weight changes in suckling ewes. J Dairy Sci 100, 125.

de Oliveira LD, Takakura FS, Kienzle E, Brunetto MA, Teshima E, et al. 2012. Fibre analysis and fibre digestibility in pet foods - a comparison of total dietary fibre, neutral and acid detergent fibre and crude fibre. J Anim Physiol Anim Nutr 96, 895-906.

de Souza NJP, He F, Mangian FH, Massae OP, De Godoy CRM. 2019. Dietary supplementation of a fiber-prebiotic and saccharin-eugenol blend in extruded diets fed to dogs. J Anim Sci 97, 4519-4531.

Demattê Filho LC, Pereira DC de O, Possamai E. 2015. Dietary supplementation of alternative methionine and choline sources in the organic broiler production in Brazil. Rev Bras Cienc Avic 17, 489-496.

Díaz Galván C, Méndez Olvera ET, Martínez Gómez D, Gloria Trujillo A, Hernández García PA, et al. 2021. Influence of a polyherbal mixture in dairy calves: growth performance and gene expression. Front Vet Sci 7, 623710.

Di Cerbo A, Morales-Medina JC, Palmieri B, Pezzuto F, Cocco R, et al. 2017. Functional foods in pet nutrition: Focus on dogs and cats. Res Vet Sci 112, 161-166.

Dilger RN, Garrow TA, Baker DH. 2007. Betaine can partially spare choline in chicks but only when added to diets containing a minimal level of choline. J Nutr 137, 2224-2228.

Donadelli AR, Aldrich GC. 2019. The effects on nutrient utilization and stool quality of Beagle dogs fed diets with beet pulp, cellulose, and Miscanthus grass. J Anim Sci 97, 4134-139.

Duque-Saldarriaga J, Posada SL, Trujillo JHA. 2017. Assessment of energy content in dog foods. Arch Zootec 66, 279-286.

Fagone P, Jackowski S. 2013. Phosphatidylcholine and the CDP-choline cycle. BBA-Mol Cell Biol L 1831, 523-532.

Farina G, De Mello KA, Diniz EP, Ritter MF, Cesar R, et al. 2017. Performance of broilers fed different dietary choline sources and levels. Ciênc Anim Bras 18, 1-14.

Felix AP, Carvalho MP, Alarça LG, Brito CBM, Oliveira SG, et al. 2012. Effects of the inclusion of carbohydrases and different soybean meals in the diet on palatability, digestibility and faecal characteristics in dogs. Anim Feed Sci Tech 174, 182-189.

Felix AP, Rivera NLM, Sabchuk TT, Lima DC, Oliveira SG, et al. 2013. The effect of soy oligosaccharide extraction on diet digestibility, fecal characteristics, and intestinal gas production in dogs. Anim Feed Sci Technol 184, 86-93.

Gabriel NN. 2019. Review on the progress in the role of herbal extracts in tilapia culture. Cogent Food Agric 5, 1619651.

German AJ, Holden SL, Serisier S, Queau Y, Biourge V. 2015. Assessing the adequacy of essential nutrient intake in obese dogs undergoing energy restriction for weight loss: a cohort study. BMC Vet Res 11, 253. 
Godínez-Cruz J, Cifuentes-López O, Cayetano J, Lee-Rangel H, Mendoza $\mathrm{G}$, et al. 2015. Effect of choline inclusion on lamb performance and meat characteristics. J Anim Sci 93, 766.

Górecki T, Smaga Ł. 2019. fdANOVA: An R software package for analysis of variance for univariate and multivariate functional data. Computation Stat 34, 571-597.

Goyal RB, Goyal KR, Mehta AA. 2007. Phyto-pharmacology of Achyranthes aspera: A Review. Pharmacogn Rev 1, 143-150.

Griffin RW, Baidler LM. 1984. Studies in Canine Olfaction, Taste and Feeding: A Summing Up and Some Comments on the AcademicIndustrial Relationship. Neurosci Biobehav Rev 8, 261-263.

Gutiérrez AR, Gutiérrez A, Sánchez C, Mendoza GD. 2019. Effect of including herbal choline in the diet of a dairy herd; a multiyear evaluation. Emir J Food Agric 31, 477-481.

Harrison M, Thomas G, Gilham M, Gray K, Colyer A, et al. 2020. Short-term determination and long-term evaluation of the dietary methionine requirement in adult dogs. Brit J Nutr 123, 1333-1344.

Hui-Chao LR, Goyanes VJJ, Couto SA, Klein DD, Valido ES, et al. 2016. Fatty acid methyl esters as a potential therapy against cerebral ischemia. $O C L 23,1-6$.

Jackson IM, Waldy C, Cochrane YC, Jewell ED. 2020. Consumption of identically formulated foods extruded under low and high shear force reveals that microbiome redox ratios accompany canine immunoglobulin A production. J Anim Physiol Anim Nutr 104, 1551-1567.

Koppel K, Adhikari K, Di Donfranceso B. 2013. Volatile compounds in dry dog foods and their influence on sensory aromatic profile. Molecules 18, 2646-2662.

Lewis ED, Richard C, Goruk S, Dellschaft NS, Curtis JM, et al. 2016. The form of choline in the maternal diet affects immune development in suckled rat offspring. $J$ Nutr $146,823-830$.

Mallo GD, Paolella M. 2017. Fuente herbal de colina en nutrición canina. Memorias del VI Congreso Argentino de Nutrición Animal, Buenos Aires, Argentina, Pp 1-5.

Martínez-Aispuro JA, Mendoza GD, Cordero-Mora JL, Ayala-Monter MA, Sánchez-Torres MT, et al. 2019. Evaluation of an herbal choline feed plant additive in lamb feedlot rations. $R$ Bras Zootec 48, e20190020.

Mendoza GD, Ortega ANI, Bárcena RG, Martínez JAG, Lee-Rangel HA. 2018. Evaluation of BioCholine and a mixture of OptiMethionine - OptiLysine in lactating Holstein cows. Final report for Indian Herbs. Universidad Autónoma Metropolitana, Xochimilco, México.

Mendoza GD, Oviedo MF, Pinos JM, Lee-Rangel HA, Vázquez A, et al. 2019. Milk production in dairy cows supplemented with herbal choline and methionine. Rev Fac Cienc Agrar 52, 332-343.

Michiels J, Missotten J, Ovyn A, Dierick N, Fremaut D, et al. 2012. Effect of dose of thymol and supplemental flavours or camphor on palatability in a choice feeding study with piglets. Czech J Anim Sci 57, 65-74.

Moghimi M, Roosta A. 2019. Physical properties of aqueous mixtures of (choline chloride + glucose) deep eutectic solvents. J Chem Thermodyn 129, 159-165.

Morrison IE, Reinhardt H, Leclerc H, DeVries JT, LeBlanc JS. 2018. Effect of rumen-protected B vitamins and choline supplementation on health, production, and reproduction in transition dairy cows. $J$ Dairy Sci 101, 9016-9027.

Mukherjee A, Sengupta S. 2013. Characterization of nimbidiol as a potent intestinal disaccharidase and glucoamylase inhibitor present in Azadirachta indica (neem) useful for the treatment of diabetes. $J$ Enzyme Inhib Med Chem 28, 900-910.

Murota K. 2020. Digestion and absorption of dietary glycerophospholipids in the small intestine: Their significance as carrier molecules of choline and n-3 polyunsaturated fatty acids. Biocatal Agric Biotechnol 26, 101633.
Nilsson Å, Rui-Dong D. 2019. Pancreatic and mucosal enzymes in choline phospholipid digestion. Am J Physiol Gastrointest Liver Physiol 316, G425-G445.

NRC, National Research Council. 2006. Nutrient requirements of dogs and cats. $3^{\text {rd }}$ ed. National Academic Press, Washington, DC, USA.

Ogbuewu IP, Odoemenam VU, Obikaonu HO, Opara MN, Emenalom OO, et al. 2011. The growing importance of neem (Azadirachta indica A. Juss) in agriculture, industry, medicine and environment: A review. Res J Med Plant 5, 230-245.

Pedrinelli V, Amorim ZRV, Ayres RRB, Pamplona PM, Consentino CRM, et al. 2019. Concentrations of macronutrients, minerals and heavy metals in home-prepared diets for adult dogs and cats. Sci Rep 9, 13058.

Pissios P, Hong S, Kennedy RA, Prasad D, Liu FF, et al. 2013. Methionine and choline regulate the metabolic phenotype of a ketogenic diet. Mol Metab 2, 306-313.

Ramzi S, Sahragard A, Sendi JJ, Aalami A. 2013. Effects of an extracted lectin from Citrullus colocynthis L. (Cucurbitaceae) on survival, digestion and energy reserves of Ectomyelois ceratoniae Zeller (Lepidoptera: Pyralidae). Front Physiol 4, 328.

Razo OPB, Mendoza MGD, Vázquez SG, Osorio TAI, González SJF, et al. 2020. Polyherbal feed additive for lambs: effects on performance, blood biochemistry and biometry. J Appl Anim Res 48, 419-424.

Roque-Jiménez JA, Mendoza-Martínez GD, Vázquez-Valladolid A, Guerrero-González ML, Flores-Ramírez R, et al. 2020. Supplemental Herbal Choline Increases 5-hmC DNA. Animals 10, 1277.

Sales J, Homolka P, Koukolova V. 2010. Effect of dietary rumen-protected choline on milk production of dairy cows: A meta-analysis. J Dairy Sci 93, 3746-3754.

Sheard NF, Zeisel HS. 1986. An in vitro study of choline uptake by intestine from neonatal adult rats. Pediatr Res 20, 768-772.

Sunvold GD, Fahey GC Jr, Merchen NR, Titgemeyer EC, Bourquin LD, et al. 1995. Dietary fiber for dogs: IV. In vitro fermentation of selected fiber sources by dog fecal inoculum and in vivo digestion and metabolism of fiber-supplemented diets. J Anim Sci 73, 1099-1109.

Tietel Z, Masaphy S. 2018. Aroma-volatile profile of black morel (Morchella importuna) grown in Israel. J Sci Food Agric 98, 346-353.

Tobie C, Perón F, Larose C. 2015. Assessing food preferences in dogs and cats: A review of the current methods. Animals 5, 126-137.

Tocher DR, Bendiksen EÅ, Campbell PJ, Bell JG. 2008. The role of phospholipids in nutrition and metabolism of teleost fish. Aquaculture 280, 21-34.

Van Soest PV, Robertson JB, Lewis BA. 1991. Methods for dietary fiber, neutral detergent fiber, and nonstarch polysaccharides in relation to animal nutrition. J Dairy Sci 74, 3583-3597.

Vance ED, Vance EJ. 2008. Phospholipid biosynthesis in eukaryotes. In: Vance ED, Vance EJ. (eds). Biochemistry of Lipids, Lipoproteins and Membranes. $5^{\text {th }}$ ed. Elsevier, Oxford, UK, Pp 213-244.

Vitali AL, Beghelli D, Biapa NPC, Bistoni O, Cappellacci L, et al. 2016. Diverse biological effects of the essential oil from Iranian Trachyspermum ammi. Arab J Chem 9, 775-786.

White D, Kim W, Shivi M. 2019. Role of Biocholine on growth performance, hepatic gene expression, and adiponectin in broilers. International Poultry Scientific Forum, Georgia World Congress Center, Atlanta, Georgia, USA, Pp 21.

Wynn SG, Fougère BJ. 2007. Veterinary Herbal Medicine: A SystemsBased Approach. In: Wynn SG, Fougère BJ (eds). Veterinary Herbal Medicine. $1^{\text {st }}$ ed. Elsevier, St. Louis, USA. Pp 29-409.

Zeisel SH, da Costa KA. 2009. Choline: an essential nutrient for public health. Nutr Rev 67, 615-623.

Zeisel HS, da Costa AK, Youssef M, Hensey S. 1989. Conversion of dietary choline to trimethylamine and dimethylamine in rats: doseresponse relationship. J Nutr 119, 800-804. 
